\title{
230 Reviews
}

Why were the first major thorough treatments of American thought only published in the last years of the Soviet Union? Ryder says the end of USSR has not been a watershed event in the study of American philosophy; since 1960 those studies had become less ideological. Still Soviet scholars continued to focus on exposing inadequacies in those philosophies as opposed to purpose of learning something.

I have some minor quibbles with Interpreting America. In places, Ryder relies heavily on exegesis and analysis of the positions of one or two philosophers, or one or two works, to set forth what then seems to be characterized as the entire Soviet response to American thought. How many Soviet philosophers worked in this area? Where did they work? Were they ensconced primarily in the Institute of Philosophy in Moscow, the conservative bastion of Soviet thought? Were there nuances or differences of interpretation among Soviet schools of American philosophy?

Ryder provides an extensive bibliography of Soviet sources, mostly from the 1960s onward, and many from 1980s and later. (Translations of works of American thinkers also appeared for the first time only in the 1990s.) The bibliography uses an inconsistent (and inaccurate) system of transliteration with the same words transliterated differently on the same page.

In sum, Interpreting America is an original, thoughtful piece of scholarship that will be of interest to advanced students of philosophy and history.

Paul Josephson

Colby College

Anthony Cross, Peter the Great through British Eyes: Perceptions and Representations of the Tsar since 1698 (Cambridge: Cambridge University Press 2000).

To refer to Anthony Cross as a leading scholar of Russian-British cultural relations is rather like calling Lance Armstrong a pretty decent bicyclist. In truth, no other English Russophile or Russian anglophile, living or dead, scholarly or popular, has contributed as much to our knowledge of English Russia and Russian Britannia. Exhibit A: His previous books include By the Banks of the Thames; By the Banks of the Neva; The Russian Theme in English Literature; Engraved in the Memory; Anglo-Russica Cambridge, Some Russian Connections; Anglo-Russian Relations in the Eighteenth Century; Catherine the Great and the British; An English Lady at the Court of Catherine the Great; Anglofiliia u trona, and...,well, my point is clear. 
Cross' latest contribution, Peter the Great through British Eyes, brings together a disparate body of materials in separate chapters on Peter's visit to Britain in 1698; anglophone historiography of the Petrine era; eighteenth and nineteenth-century British caricatures of Peter; theatrical representations; and Peter in British publicism during the eighteenth and early nineteenth centuries. The chapter on Peter's Great Embassy, and the extended visit to England in 1698, is particularly lively, especially the tale of Peter's paramour pro tem (and the author's namesake), the noted London stage actress Letitia Cross. The raucous behavior of the Tsar's party, the damage they inflicted by trashing more than one guest house, the drain on the treasury of George I (which was subsidizing Peter's four-month stay at the rate of 40 pounds per diem), all receive vivid display. Peter, as Cross recounts, was either unmoved or oblivious, and his merriment continued as unabated as were his curiosities over everything naval and technological. The subsequent legends of this visit, especially their depiction in British drama, are equally lively. By contrast, the passages detailing British and general anglophone historiography are more prosaic, straightforward and accurate, but lacking the vivacity of the other sections. The epilogue, which recounts in a few pages the contributions of the last half-century of British historians to Petriniana, seems somewhat disconnected from the rest of the work.

One sub-theme running through the entire text is the interplay of foreign policy and representations of the Tsar, in particular the clash and co-existence of empires. Russia's simultaneous emergence as an empire and as a sea power during the Petrine era transformed both the image and the gravitas of representation, in particular caricature. The double-edged sword of Russia's Europeanness now replaced the seventeenth-century imagery of incivility and exotica. The new discursive poles were backwardness (bad old belligerent Russia) and cultural progress (good young Russia), each invariably bracketed with the current state of Anglo-Russian relations.

Backward Russia was predicatably aggressive, expansionist, brutal; European Russia was cooperative, measured, a force for stability. Writing in 1710 , for example, Jonathan Steele congratulated Peter for "the crucial decision not to turn to France, 'the nation from which the rest of the World has borrowed its politeness." Instead, Peter chose the path of "honest labor" and "“[b]y this means has this great Prince laid the foundation of a great and lasting Fame." (46). The good Russia was, at heart, not so different from Britain, while the bad Russia was an untamable savage. Thus, in 1718 Aaron Hill could poetize: "Britain and Russia differ, but in name. In nature's sense, all nations are the same. One world, divided, distant brothers share, And man is reason's subject - everywhere." (49). A few years earlier, though, when talk of Russian atrocities in Finland was rife, Daniel Defoe coined the exquisitely racialized 


\section{Reviews}

epithet "Russian Mohawks," thus mobilizing the Enlightenment's full arsenal of vituperative metaphors of race, geography, and incivility in one simple construction.

A curious and possibly important undercurrent in British popular imagery, both positive and negative, was the ongoing interest in Peter's troubled relationship with his son Alexis, a relationship that ultimately led to Alexis' execution for treason. Somehow this sad episode held special meaning for British publicists, as if it encapsulated some essential truth about Peter and Russia. But what? What does this ongoing fascination with the execution of the regent tell us about British political sensibilities or their assumptions about civilized kingship? Here, as elsewhere, the reader must draw his/her own inferences.

Cross eschews simple political conclusions from his material. Neither does he impose any specific interpretive model on it. He describes the book tellingly as "a wide-ranging survey that embraces all forms of written evidence as well as visual images." Here, as in much of his previous scholarship on Russia and Britain, he delights in offering rich descriptions of little-known material, and then allow the readers to make of it what they will. This approach to narration is both pleasing and slightly frustrating. Pleasing because it places the primary material at center stage and it avoids forcing cultural ambiguities and cross currents into a single rigid model. Frustrating because it deprives the reader of the author's own readings of his materials, his sense of their significance in grasping the geo-politics of culture. Living as we do in a time when the cultural symbols and material interests of states and peoples are intertwined with powerful and often violent consequences, it would be instructive to apply these heightened sensibilities to past time, especially if it were done by someone with the expertise and erudition of Anthony Cross. From that single perspective this book, otherwise so engaging and consistently attentive to detail, is something of a missed opportunity.

Gary Marker

State University of New York at Stony Brook

Gary Kinsman, Dieter K. Buse and Mercedes Steedman, eds., Whose National Security? Canadian State Surveillance and the Creation of Enemies (Toronto: Between The Lines, 2000).

This collection originated in a 1996 conference at Laurentian University which brought together critical researchers and Left activists concerned with understanding and critiquing dominant notions of Canada's "national security." 